\title{
MELATONIN IMPROVES LIVER FUNCTION IN BENZENE-TREATED RATS
}

\author{
Seema SHARMA and Suresh Vir Singh RANA \\ Toxicology Laboratory, Department of Zoology, Ch. Charan Singh University Meerut, Meerut, India \\ Received in April 2012 \\ CrossChecked in October 2012 \\ Accepted in November 2012
}

\begin{abstract}
In this study, we investigated the beneficial effects of melatonin against benzene-induced liver function impairments in Wistar rats. After 30 days of treatment, it significantly lowered hepatosomatic indices, bilirubin, and hydroxyproline in male and female benzene-treated rats. Even though it did not influence aspartate aminotransferase, melatonin had beneficial effects on alanine aminotransferase and alkaline phosphatase. Our results suggest that melatonin is an effective modulator of liver function in benzenetreated rats thanks to its antioxidative properties.
\end{abstract}

KEY WORDS: alkaline phosphatase, antioxidants, bilirubin, hydroxyproline, serum transaminases

Benzene is a volatile aromatic hydrocarbon widely used in industry as a solvent. A number of sources such as cigarette smoke, gasoline, and vehicle exhausts contaminate the environment with it $(1,2)$. Benzene has been evidenced to cause leukaemia and cancer in man and animals (3-5).

Gonasun (6) reported benzene metabolism in mouse liver microsomes. Sawahata and Neal (7) studied the biotransformation of phenol, benzene's major metabolite, to hydroquinone and catechol by rat liver microsomes. Arinç et al. (8) studied the effects of benzene on $\mathrm{CYP}_{450}$-dependent drug-metabolising enzymes (8). In a comprehensive review of various occupational agents, Bacarelli (9) reports about benzene effects on endocrine glands, including the pituitary, in experimental animals and humans. Benzene, toluene, and xylene seem to affect semen quality and the function of accessory glands in exposed workers (10). Benzene induces histopathological lesions to the mouse testis (11). Benzene fumes also affect endocrine activity in rats (12).

It is generally agreed that benzene needs to metabolise to manifest its toxic effects. Oxidative metabolites (epoxides, free radicals, aldehyde, and quinones) of benzene destroy $\mathrm{CYP}_{450} 2 \mathrm{E} 1$ (13) and are believed to be responsible for its carcinogenic effects. In an earlier study we investigated the role of oxidative stress in benzene toxicity in rat liver, kidney, and lungs (14).

Melatonin (N-acetyl-methoxytryptamine) functions as a "time giver" (zeitgeber) in the regulation of circadian rhythm (15). It is mostly synthesised at night (16). A series of experiments made in our laboratory suggests that hormones change the metabolic disposition of drugs/chemicals (17-21).

However, the effects of melatonin on benzene metabolism and toxicity have not been studied so far. Recently, Reiter (22) described an intriguing antioxidant property of melatonin. An earlier report from our laboratory (23) has shown that melatonin protects against benzene-induced lipid peroxidation in rat liver. This study continues to investigate the protective effects of melatonin, this time against benzene-induced damage of the liver function in rats. 


\section{MATERIALS AND METHODS}

Sixty male and sixty female three-month-old Wistar rats $(150 \mathrm{~g} \pm 20 \mathrm{~g})$ procured from Jamia Hamdard animal facility in New Delhi were acclimatised to laboratory conditions [room temperature $(25 \pm 5){ }^{\circ} \mathrm{C}$, humidity $(50 \pm 10) \%$, 12 -hour dark/light cycle] for 2 weeks. The rats were distributed in four treatment arms, as follows: control - receiving $0.2 \mathrm{~mL}$ of $2 \%$ olive oil alone; melatonin - receiving $0.25 \mathrm{~mL}$ of $2 \%$ melatonin alone; benzene - receiving $0.2 \mathrm{~mL}$ of $2 \%$ benzene alone; and benzene + melatonin - receiving both compounds in the above doses one hour apart. The treatment groups were further divided in three subgroups with ten animals each according to exposure/treatment duration, i.e. $24 \mathrm{~h}, 15$ days, and 30 days.

All animal treatments and protocols had been approved by the Institutional Ethics Committee before we started the experiment.

\section{Treatment}

Benzene (AR grade) was procured from S-Merck (Mumbai, India). Predetermined sublethal dose of $0.2 \mathrm{~mL}$ of $2 \%$ benzene in olive oil (14) was administered by intramuscular injection at 08:00 a.m. every other day. Melatonin (N-acetyl methoxytryptamine, Sigma Chemical Company, St. Louis, MO, USA) was injected intraperitoneally in the dose of $0.25 \mathrm{~mL}$ per $100 \mathrm{~g}$ of body weight one hour later (at 9:00 a.m.), as described earlier (23).

Rats were killed under light ether anaesthesia $24 \mathrm{~h}$ after the last treatment dose. Over these $24 \mathrm{~h}$, they did not receive any food. Blood was collected from the heart. Serum was separated by centrifugation and processed for liver function tests.

\section{Serum transaminases}

Serum transaminases were determined according to the method described by Reitman and Frankel (24). 2,4-dinitrophenyl hydrazine, aspartate aminotransferase (AST) substrate, alanine aminotransferase (ALT) substrate, and pyruvate standard were supplied in the commercial kit procured from Span Diagnostics (Surat, India). Absorbance was recorded at $510 \mathrm{~nm}$ using a Systronics visual spectrophotometer (Ahmedabad, India).

\section{Total bilirubin}

Serum bilirubin was determined using a commercial kit procured from Ozone Biochemicals Pvt. Ltd. (Gurgaon, India) following the method of Burtis and

Table 1 Effect of melatonin on the hepatosomatic index (HSI) of benzene treated rats.

\begin{tabular}{|c|c|c|c|c|}
\hline \multirow{2}{*}{ Sex } & \multirow{2}{*}{ Treatments } & \multicolumn{3}{|c|}{ HSI } \\
\hline & & $24 \mathrm{~h}$ & 15 days & 30 days \\
\hline \multirow{9}{*}{ Male } & \multirow{2}{*}{ Control } & $4.96 \pm 0.251$ & $4.18 \pm 0.232$ & $4.21 \pm 0.238$ \\
\hline & & (4.23 to 5.93 ) & (3.43 to 4.84$)$ & (3.42 to 4.96 ) \\
\hline & \multirow{2}{*}{ Melatonin } & $4.83 \pm 0.192 *$ & $4.19 \pm 0.264^{*}$ & $4.46 \pm 0.183^{*}$ \\
\hline & & (4.32 to 5.43$)$ & (3.22 to 4.69$)$ & (3.80 to 5.07$)$ \\
\hline & \multirow{2}{*}{ Melatonin + benzene } & $5.87 \pm 0.059^{*}$ & $4.15 \pm 0.260 *$ & $4.35 \pm 0.360^{*}$ \\
\hline & & (5.68 to 6.01$)$ & (3.18 to 4.85$)$ & (3.45 to 5.63 ) \\
\hline & \multirow{2}{*}{ Benzene } & $7.10 \pm 0.141^{\text {N.S. }}$ & $4.37 \pm 0.251^{*}$ & $4.89 \pm 0.357^{*}$ \\
\hline & & (6.80 to 7.61$)$ & (3.35 to 5.01 ) & (3.55 to 5.98$)$ \\
\hline & F Value & 28.53 & 0.1265 & 0.7947 \\
\hline \multirow{9}{*}{ Female } & \multirow{2}{*}{ Control } & $4.54 \pm 0.329$ & $3.65 \pm 0.223$ & $4.09 \pm 0.133$ \\
\hline & & (3.76 to 5.94$)$ & (3.10 to 4.50$)$ & (3.75 to 4.63 ) \\
\hline & \multirow{2}{*}{ Melatonin } & $4.19 \pm 0.217 *$ & $4.04 \pm 0.129 *$ & $3.75 \pm 0.174 *$ \\
\hline & & (4.05 to 4.93$)$ & (3.71 to 4.50$)$ & (3.33 to 4.39$)$ \\
\hline & \multirow{2}{*}{ Melatonin + benzene } & $5.06 \pm 0.181 *$ & $3.83 \pm 0.374^{*}$ & $4.41 \pm 0.512 *$ \\
\hline & & (4.43 to 5.57$)$ & (2.76 to 4.93$)$ & (3.73 to 6.69$)$ \\
\hline & \multirow{2}{*}{ Benzene } & $6.71 \pm 0.144^{\text {N.S. }}$ & $3.93 \pm 0.217^{*}$ & $4.25 \pm 0.181^{\text {N.S. }}$ \\
\hline & & (6.10 to 7.05$)$ & (3.24 to 4.63$)$ & (3.71 to 4.80$)$ \\
\hline & F Value & 19.77 & 0.3492 & 0.7399 \\
\hline
\end{tabular}

Results are expressed as mean \pm S.E. $(\mathrm{n}=5)$

* denotes values significantly different from control $(\mathrm{p} \leq 0.05)$.

N.S. denotes non significant differences from control.

Values in parenthesis indicate the range. 
Table 2 Effect of melatonin on the total bilirubin in the serum of benzene treated rats.

\begin{tabular}{|c|c|c|c|c|}
\hline \multirow{2}{*}{ Gender } & \multirow{2}{*}{ Treatments } & \multicolumn{3}{|c|}{ Total bilirubin / mg per $100 \mathrm{~mL}$} \\
\hline & & $24 \mathrm{~h}$ & 15 days & 30 days \\
\hline \multirow{9}{*}{ Male } & \multirow{2}{*}{ Control } & $1.370 \pm 0.226$ & $1.370 \pm 0.100$ & $1.380 \pm 0.228$ \\
\hline & & $(0.80$ to 2.08$)$ & $(1.02$ to 1.75$)$ & $(0.80$ to 2.08$)$ \\
\hline & \multirow{2}{*}{ Melatonin } & $0.960 \pm 0.124^{*}$ & $2.760 \pm 0.130^{\text {N.S. }}$ & $1.450 \pm 0.284^{*}$ \\
\hline & & $(0.574$ to 1.379$)$ & $(2.30$ to 3.20$)$ & $(0.804$ to 0.230$)$ \\
\hline & \multirow{2}{*}{ Melatonin + benzene } & $1.260 \pm 0.107^{*}$ & $1.300 \pm 0.040^{*}$ & $1.940 \pm 0.128^{*}$ \\
\hline & & (0.919 to 1.494$)$ & (1.12 to 1.45$)$ & (1.60 to 2.31$)$ \\
\hline & \multirow{2}{*}{ Benzene } & $1.080 \pm 0.140 *$ & $3.700 \pm 0.180^{\text {N.S. }}$ & $4.810 \pm 0.142^{\text {N.S. }}$ \\
\hline & & (0.574 to 1.494$)$ & $(3.0$ to 4.2$)$ & (4.32 to 5.13$)$ \\
\hline & F Value & 1.145 & 60.54 & 62.42 \\
\hline \multirow{9}{*}{ Female } & \multirow{2}{*}{ Control } & $0.680 \pm 0.134$ & $1.470 \pm 0.072$ & $2.190 \pm 0.373$ \\
\hline & & $(0.344$ to 1.149$)$ & (1.25 to 1.68$)$ & (1.03 to 3.13$)$ \\
\hline & \multirow{2}{*}{ Melatonin } & $1.700 \pm 0.119^{\text {N.S. }}$ & $3.100 \pm 0.230^{\text {N.S. }}$ & $3.160 \pm 0.291^{\text {N.S. }}$ \\
\hline & & (1.264 to 2.068$)$ & (2.3 to 3.8$)$ & (2.3 to 3.89$)$ \\
\hline & \multirow{2}{*}{ Melatonin + benzene } & $2.750 \pm 0.134^{\text {N.S. }}$ & $1.410 \pm 0.060^{\text {N.S. }}$ & $3.830 \pm 0.205^{\text {N.S. }}$ \\
\hline & & (2.298 to 3.103$)$ & (1.28 to 1.65$)$ & (3.15 to 4.34$)$ \\
\hline & \multirow{2}{*}{ Benzene } & $7.050 \pm 0.155^{\text {N.S. }}$ & $4.080 \pm 0.110^{\text {N.S. }}$ & $2.460 \pm 0.178^{*}$ \\
\hline & & (6.436 to 7.471$)$ & $(3.75$ to 4.50$)$ & (1.91 to 2.85$)$ \\
\hline & F Value & 339.1 & 65.61 & 7.234 \\
\hline
\end{tabular}

Results are expressed as mean \pm S.E. $(\mathrm{n}=5)$

* denotes values significantly different from control $(\mathrm{p} \leq 0.05)$.

N.S. denotes non significant differences from control.

Values in parenthesis indicate the range.

Table 3 Effect of melatonin on the urinary hydroxyproline of benzene treated rats.

\begin{tabular}{|c|c|c|c|c|}
\hline \multirow{2}{*}{ Sex } & \multirow{2}{*}{ Treatments } & \multicolumn{3}{|c|}{ Hydroxyproline / mg L L } \\
\hline & & $24 \mathrm{~h}$ & 15 days & 30 days \\
\hline \multirow{9}{*}{ Male } & \multirow[t]{2}{*}{ Control } & $4.06 \pm 0.172$ & $3.73 \pm 0.125$ & $3.82 \pm 0.851$ \\
\hline & & (3.6 to 4.5$)$ & (3.73 to 4.25$)$ & (3.43 to 4.20$)$ \\
\hline & \multirow[t]{2}{*}{ Melatonin } & $4.15 \pm 0.139 *$ & $4.04 \pm 0.213^{*}$ & $6.43 \pm 0.207^{\text {N.S. }}$ \\
\hline & & (3.7 to 4.5$)$ & (3.5 to 4.7 ) & (5.75 to 6.93$)$ \\
\hline & \multirow[t]{2}{*}{ Melatonin + benzene } & $6.40 \pm 0.188^{*}$ & $5.54 \pm 0.209^{*}$ & $5.70 \pm 0.256^{*}$ \\
\hline & & (5.92 to 6.83$)$ & (4.93 to 6.15$)$ & (4.9 to 6.4 ) \\
\hline & \multirow[t]{2}{*}{ Benzene } & $8.14 \pm 0.250^{\text {N.S. }}$ & $7.44 \pm 0.263^{\text {N.S. }}$ & $7.09 \pm 0.125^{\text {N.S. }}$ \\
\hline & & (7.5 to 8.9$)$ & (6.7 to 8.1$)$ & (6.73 to 7.40$)$ \\
\hline & F Value & 104.6 & 61.76 & 53.97 \\
\hline \multirow{9}{*}{ Female } & \multirow[t]{2}{*}{ Control } & $3.40 \pm 0.209$ & $3.27 \pm 0.189$ & $3.39 \pm 0.261$ \\
\hline & & (2.7 to 3.9$)$ & (2.8 to 3.78$)$ & (2.83 to 4.2$)$ \\
\hline & \multirow[t]{2}{*}{ Melatonin } & $5.02 \pm 0.062^{\text {N.S. }}$ & $4.23 \pm 0.071^{\text {N.S. }}$ & $6.18 \pm 0.220^{\text {N.S. }}$ \\
\hline & & (4.83 to 5.18$)$ & $(3.98$ to 4.39$)$ & (5.6 to 6.8$)$ \\
\hline & \multirow[t]{2}{*}{ Melatonin + benzene } & $4.88 \pm 0.196^{*}$ & $6.06 \pm 0.177^{*}$ & $5.40 \pm 0.222 *$ \\
\hline & & (4.3 to 5.5$)$ & (5.6 to 6.6 ) & (4.85 to 5.98$)$ \\
\hline & \multirow[t]{2}{*}{ Benzene } & $6.77 \pm 0.144^{\text {N.S. }}$ & $6.10 \pm 0.251^{\text {N.S. }}$ & $6.44 \pm 0.191^{\text {N.S. }}$ \\
\hline & & $(6.23$ to 7.03$)$ & (5.5 to 6.9$)$ & (5.83 to 6.93$)$ \\
\hline & F Value & 71.26 & 57.85 & 37.65 \\
\hline
\end{tabular}

Results are expressed as mean \pm S.E. $(\mathrm{n}=5)$

* denotes values significantly different from control $(\mathrm{p} \leq 0.05)$.

N.S. denotes non significant differences from control.

Values in parenthesis indicate the range. 
Table 4 Effect of melatonin on the alkaline phosphatase (ALP) activity in the serum of benzene treated rats.

\begin{tabular}{|c|c|c|c|c|}
\hline \multirow{2}{*}{ Sex } & \multirow{2}{*}{ Treatments } & \multicolumn{3}{|c|}{ ALP activity / Karmen unit } \\
\hline & & $24 \mathrm{~h}$ & 15 days & 30 days \\
\hline \multirow{9}{*}{ Male } & \multirow[t]{2}{*}{ Control } & $12.420 \pm 3.030$ & $12.440 \pm 0.190$ & $12.41 \pm 0.266$ \\
\hline & & (5.05 to 21.0$)$ & (11.8 to 13.0$)$ & (11.7 to 13.2$)$ \\
\hline & \multirow[t]{2}{*}{ Melatonin } & $28.570 \pm 0.518^{\text {N.S. }}$ & $17.800 \pm 0.250^{\text {N.S. }}$ & $14.03 \pm 0.021^{\text {N.S. }}$ \\
\hline & & (27.03 to 30.29 ) & (17 to 18.6$)$ & (13.91 to 14.98$)$ \\
\hline & \multirow[t]{2}{*}{ Melatonin + benzene } & $26.110 \pm 0.371 *$ & $20.180 \pm 0.290 *$ & $18.60 \pm 0.153^{*}$ \\
\hline & & (24.77 to 26.94 ) & (19.3 to 21.3 ) & (13.9 to 23.1 ) \\
\hline & \multirow[t]{2}{*}{ Benzene } & $22.360 \pm 0.260^{\text {N.S. }}$ & $27.700 \pm 0.059^{\text {N.S. }}$ & $19.90 \pm 0.107^{\text {N.S. }}$ \\
\hline & & (21.55 to 23.29$)$ & (26.3 to 30.3$)$ & (17.0 to 23.0$)$ \\
\hline & F Value & 20.65 & 217.3 & 13.77 \\
\hline \multirow{9}{*}{ Female } & \multirow[t]{2}{*}{ Control } & $20.800 \pm 0.455$ & $15.040 \pm 0.210$ & $12.52 \pm 0.234$ \\
\hline & & (19.59 to 22.33$)$ & (14.3 to 15.8$)$ & (11.98 to 13.31$)$ \\
\hline & \multirow[t]{2}{*}{ Melatonin } & $9.160 \pm 0.347^{\text {N.S. }}$ & $13.160 \pm 0.170^{\text {N.S. }}$ & $14.12 \pm 0.184^{\text {N.S. }}$ \\
\hline & & (18.12 to 10.29$)$ & (12.7 to 13.9$)$ & (13.71 to 14.63$)$ \\
\hline & \multirow[t]{2}{*}{ Melatonin + benzene } & $19.330 \pm 0.374^{*}$ & $17.100 \pm 0.180^{*}$ & $17.12 \pm 0.203^{*}$ \\
\hline & & (18.25 to 20.46$)$ & (16.6 to 17.8$)$ & (16.5 to 17.6$)$ \\
\hline & \multirow[t]{2}{*}{ Benzene } & $15.710 \pm 0.643^{\text {N.S. }}$ & $20.100 \pm 0.390^{\text {N.S. }}$ & $19.70 \pm 0.097^{\text {N.S. }}$ \\
\hline & & (13.81 to 17.68$)$ & (18.6 to 21.3$)$ & (13.5 to 19.37$)$ \\
\hline & F Value & 98.11 & 97.08 & 155 \\
\hline
\end{tabular}

Results are expressed as mean \pm S.E. $(\mathrm{n}=5)$

$*$ denotes values significantly different from control $(\mathrm{p} \leq 0.05)$.

N.S. denotes non significant differences from control.

Values in parenthesis indicate the range.

Table 5 Effect of melatonin on the aspartate transaminase (AST) activity in the serum of benzene treated rats.

\begin{tabular}{|c|c|c|c|c|}
\hline \multirow{2}{*}{ Sex } & \multirow{2}{*}{ Treatments } & \multicolumn{3}{|c|}{ AST activity / Karmen unit } \\
\hline & & $24 \mathrm{~h}$ & 15 days & 30 days \\
\hline \multirow{5}{*}{ Male } & Control & $\begin{array}{l}42.40 \pm 4.400 \\
(30.0 \text { to } 52.0)\end{array}$ & $\begin{array}{l}42.80 \pm 1.590 \\
(38.0 \text { to } 48.0)\end{array}$ & $\begin{array}{l}41.80 \pm 3.786 \\
(31.0 \text { to } 47.0)\end{array}$ \\
\hline & Melatonin & $\begin{array}{l}275.6 \pm 1.460^{\text {N.S. }} \\
(271.0 \text { to } 280.0)\end{array}$ & $\begin{array}{c}50.80 \pm 1.760^{\text {N.S. }} \\
(46.0 \text { to } 58.0)\end{array}$ & $\begin{array}{l}45.40 \pm 3.075^{*} \\
(37.0 \text { to } 53.0)\end{array}$ \\
\hline & Melatonin + benzene & $\begin{array}{l}340.2 \pm 1.030^{\text {N.S. }} \\
(337.0 \text { to } 344.0)\end{array}$ & $\begin{array}{l}31.40 \pm 1.640^{*} \\
(27.0 \text { to } 38.0)\end{array}$ & $\begin{array}{l}58.00 \pm 4.816^{*} \\
(41.0 \text { to } 69.0)\end{array}$ \\
\hline & Benzene & $\begin{array}{l}330.6 \pm 1.220^{\text {N.S. }} \\
(327.0 \text { to } 335.0)\end{array}$ & $\begin{array}{c}36.40 \pm 2.000^{\text {N.S. }} \\
(30.0 \text { to } 43.0)\end{array}$ & $\begin{array}{c}68.20 \pm 3.891^{\text {N.S. }} \\
(57.0 \text { to } 79.0\end{array}$ \\
\hline & F Value & 3085 & 16.74 & 9.414 \\
\hline \multirow{5}{*}{ Female } & Control & $\begin{array}{c}120.8 \pm 5.240 \\
(122.0 \text { to } 198.0)\end{array}$ & $\begin{array}{c}76.00 \pm 1.950 \\
(70.0 \text { to } 82.0)\end{array}$ & $\begin{array}{c}72.20 \pm 3.967 \\
(63.0 \text { to } 86.0)\end{array}$ \\
\hline & Melatonin & $\begin{array}{l}239.6 \pm 1.280^{\text {N.S. }} \\
(235.0 \text { to } 243.0)\end{array}$ & $\begin{array}{c}40.20 \pm 1.590^{\text {N.S. }} \\
(35.0 \text { to } 46.0)\end{array}$ & $\begin{array}{c}62.20 \pm 2.634^{\text {N.S. }} \\
(59.0 \text { to } 71.0)\end{array}$ \\
\hline & Melatonin + benzene & $\begin{array}{c}265.4 \pm 1.460 * \\
(261.0 \text { to } 270.0)\end{array}$ & $\begin{array}{l}45.00 \pm 1.466^{*} \\
(40.0 \text { to } 50.0)\end{array}$ & $\begin{array}{l}44.80 \pm 2.437^{*} \\
(37.0 \text { to } 51.0)\end{array}$ \\
\hline & Benzene & $\begin{array}{l}142.8 \pm 1.660^{\text {N.S. }} \\
(137.0 \text { to } 148.0)\end{array}$ & $\begin{array}{c}42.20 \pm 1.840^{\text {N.S. }} \\
(37.0 \text { to } 49.0)\end{array}$ & $\begin{array}{c}72.20 \pm 2.817^{\text {N.S. }} \\
(65.0 \text { to } 81.0)\end{array}$ \\
\hline & F Value & 78.29 & 70.46 & 18.27 \\
\hline
\end{tabular}

Results are expressed as mean \pm S.E. $(\mathrm{n}=5)$

$*$ denotes values significantly different from control $(\mathrm{p} \leq 0.05)$.

N.S. denotes non significant differences from control.

Values in parenthesis indicate the range. 
Table 6 Effect of melatonin on the alanine transaminase (ALT) activity in the serum of benzene treated rats.

\begin{tabular}{|c|c|c|c|c|}
\hline \multirow{2}{*}{ Sex } & \multirow{2}{*}{ Treatments } & \multicolumn{3}{|c|}{ ALT activity / Karmen unit } \\
\hline & & $24 \mathrm{~h}$ & 15 days & 30 days \\
\hline \multirow{9}{*}{ Male } & \multirow[t]{2}{*}{ Control } & $71.80 \pm 2.033$ & $71.40 \pm 1.749$ & $71.00 \pm 3.741$ \\
\hline & & (65.0 to 78.0$)$ & $(67.0$ to 76.0$)$ & $(61.0$ to 80.0$)$ \\
\hline & \multirow[t]{2}{*}{ Melatonin } & $67.60 \pm 1.715^{*}$ & $140.0 \pm 2.830^{\text {N.S. }}$ & $105.6 \pm 6.185^{\text {N.S. }}$ \\
\hline & & (62.0 to 73.0$)$ & (130.0 to 148.0$)$ & (88.0 to 120.0$)$ \\
\hline & \multirow[t]{2}{*}{ Melatonin + benzene } & $61.60 \pm 2.816^{*}$ & $124.4 \pm 1.890 *$ & $82.80 \pm 5.739 *$ \\
\hline & & $(50.0$ to 68.0$)$ & (118.0 to 130.0$)$ & (87.0 to 103.0$)$ \\
\hline & \multirow[t]{2}{*}{ Benzene } & $66.00 \pm 1.360^{\text {N.S. }}$ & $127.2 \pm 2.210^{\text {N.S. }}$ & $83.80 \pm 7.598^{*}$ \\
\hline & & $(62.0$ to 70.0$)$ & (121.0 to 135.0$)$ & (65.0 to 108.0$)$ \\
\hline & F Value & 3.391 & 144.60 & 5.961 \\
\hline \multirow{9}{*}{ Female } & \multirow[t]{2}{*}{ Control } & $62.60 \pm 1.594$ & $84.20 \pm 1.960$ & $94.80 \pm 7.480$ \\
\hline & & (58.0 to 68.0$)$ & $(78.0$ to 90.0$)$ & (75.0 to 115.0$)$ \\
\hline & \multirow[t]{2}{*}{ Melatonin } & $73.20 \pm 1.537^{\text {N.S. }}$ & $105.2 \pm 2.070^{\text {N.S. }}$ & $110.0 \pm 4.959 *$ \\
\hline & & (69.0 to 78.0$)$ & (98.0 to 112.0$)$ & (95.0 to 125.0$)$ \\
\hline & \multirow[t]{2}{*}{ Melatonin + benzene } & $71.00 \pm 0.896^{*}$ & $138.6 \pm 1.940 *$ & $84.20 \pm 7.358^{*}$ \\
\hline & & (68.0 to 74.0$)$ & (132.0 to 145.0$)$ & (63.0 to 103.0$)$ \\
\hline & \multirow[t]{2}{*}{ Benzene } & $68.20 \pm 1.280^{\text {N.S. }}$ & $143.8 \pm 2.020^{\text {N.S. }}$ & $87.80 \pm 5.686^{*}$ \\
\hline & & (64.0 to 72.0$)$ & (138.0 to 150.0$)$ & (72.0 to 105.0$)$ \\
\hline & F Value & 9.189 & 150.80 & 3.119 \\
\hline
\end{tabular}

Results are expressed as mean \pm S.E. $(\mathrm{n}=5)$

* denotes values significantly different from control $(\mathrm{p} \leq 0.05)$

N.S. denotes non significant differences from control.

Values in parenthesis indicate the range.

Ashwood (25). Absorbance was recorded at $540 \mathrm{~nm}$ using a Systronics visual spectrophotometer (Ahmedabad, India).

\section{Alkaline phosphatase}

Serum alkaline phosphatase (ALP) was determined using a commercial kit procured from Span Diagnostics (Surat, India), following the method described by Kind and King (26).

\section{Hydroxyproline}

Hydroxyproline was estimated in urine samples using the colorimetric method of Pondenphant et al. (27). Absorbance was recorded at $550 \mathrm{~nm}$ using a Systronics visual spectrophotometer (Ahmedabad, India).

\section{Statistical analysis}

Student's $t$-test was used to compare differences between the experimental groups. The level of significance between means was set at $p<0.05$. All calculations were performed using the IBM SPSS software (IBM, New Delhi, India). Inter-group comparisons were made using one-way analysis of variance (ANOVA).

\section{RESULTS}

Benzene treatment increased the hepatosomatic index (liver to body weight ratio) of both male and female rats, but was higher in male rats. However, melatonin seems to have countered its effects in the benzene + melatonin arm (Table 1). Similar was found for bilirubin (Table 2) and hydroxyproline (Table 3).

Benzene also increased ALP, more so in male than in female rats. Melatonin countered the effects of benzene only after 15 and 30 days of treatment (Table 4).

AST significantly increased after $24 \mathrm{~h}$ of benzene treatment. Its activity dropped after 15 days, but increased again after 30 days. Melatonin showed no significant effect on AST activity (Table 5).

At hour 24, benzene lowered ALT activities in male, but increased them in female rats. Enzyme activities increased after 15 days of treatment and then 
dropped on treatment day 30 , still remaining above control activities. Melatonin following benzene treatment did not significantly lower enzyme levels in either male or female rats, regardless of treatment duration (Table 6).

\section{DISCUSSION}

An earlier report from our laboratory has shown that benzene is a potent hepatotoxin (28). Our gene expression study (29) also confirmed that downregulation of CYP2610 and CYP4A10 genes after benzene treatment accounts for biochemical and histopathological changes in BALB/c mice. We also observed that circadian rhythm affects benzeneinduced lipid peroxidation (30). Another benzeneinduced lipid peroxidation modulator in rat liver that we found was melatonin (23). This urged us to find out how much in fact melatonin protects the liver in benzene-treated rats. Although the effects of a few other hormones have been described earlier (31), this is the first report on such effects by melatonin. The action of melatonin, however, is not restricted to neuroendocrine physiology. Since 1993, melatonin has been known to scavenge ROS, including singlet oxygen $\left(\mathrm{O}_{2}\right)$, superoxide anion radical $\left(\mathrm{O}_{2}{ }^{\circ}\right)$, hydrogen peroxide $\left(\mathrm{H}_{2} \mathrm{O}_{2}\right)$, hydroxyl radical ( $(\mathrm{OH})$, and lipid peroxide radical (LOO') (32-35). It also acts as an indirect antioxidant through the activation of major antioxidant enzymes including SOD, CAT, and GPx (36-37). Improved liver function after melatonin treatment seems to be a consequence of this effect.

In the first $24 \mathrm{~h}$, melatonin could not stop transaminases to leak into the bloodstream of benzenetreated rats. This can be explained by the enormous functional reserves of the liver parenchyma. Serum enzyme activities regress as the injury progresses, which suggests that substantial serum AST or ALT does not necessarily reflect cell death. AST is found in a wide variety of tissues beside liver, including heart, skeletal muscles, kidney, and brain, whereas ALT appears to be primarily located in the liver (38).

Our alkaline phosphatase findings seem to confirm the protective effects of melatonin against benzeneinduced hepatotoxicity. Several physiological factors have been reported to affect serum AP activity including age, sex, and gestation (39). Elevations in serum AP are associated with a wide variety of lesions beside the liver. In other words, benzene could have raised serum AP levels through both hepatic and nonhepatic disorders (40). Melatonin may have acted through several physiological effects on serum alkaline phosphatase activity, such as membrane stabilisation and reduced electron leakage (41).

All groups that received benzene had higher serum bilirubin. Bilirubin is mainly derived from the haem moiety of haemoglobin, liberated when the affected red cells are removed from circulation by the reticuloendothelial system (42). Hyperbilirubinaemia is not considered sensitive enough for early detection of parenchymal liver disease (43), which explains why 24-hour exposure to benzene did not result in hyperbilirubinaemia. However, 15 and 30-day exposure did. In the benzene + melatonin groups, melatonin seems to have exerted its protective effects, probably through glucuronidation of benzene metabolites (phenol, catechol, and hydroquinone) (44). Phase-I biotransformation products are deactivated by phase-II biotransformation reactions, including glucuronidation, sulphonation, acetylation, methylation, and the formation of mercapturic acid. Glucuronidation may have increased the hydrophilicity of phenol/hydroquinone/catechol, promoting their excretion. Since phase-II enzymes are located mainly in the cytosol, these reactions occur faster than phaseI reactions. Melatonin might have contributed to detoxification by stimulating responsible phase-II enzymes.

Hydroxyproline is a reliable marker of collagen metabolism. Morphologic and biochemical alterations in collagen occur under diverse pathological conditions (45). However, the effects of benzene on collagen have not yet been studied. Our results show that benzene disturbs collagen metabolism. Melatonin treatment, in turn, inhibits collagenolysis and thus restores hydroxyproline to normal levels.

Our findings suggest that melatonin can be used to buffer benzene toxicity in solvent industry workers. Reiter et al. (46) have discussed the pathophysiological implications of melatonin against free radicalmediated disorders. Effects of melatonin as an antioxidant include (i) direct free radical scavenging; (ii) stimulation of antioxidant enzymes; and (iii) boosting the efficiency of mitochondrial oxidative phosphorylation and other antioxidants. Other laboratories have conducted similar experiments with other antioxidants such as quercetin (47). Since benzene-induced hepatotoxicity primarily involves oxidative stress (48), melatonin owes a large part of its protective effect to its antioxidative properties. 
Further studies of antioxidant enzymes are needed to support of this conclusion.

\section{REFERENCES}

1. Paustenbach DJ, Bass RD, Price P. Benzene toxicity and risk assessment, 1972-1992: implications for further regulation. Environ Health Perspect 1993;101(Suppl 6):177-200.

2. Kenyon EM, Kraichely RE, Hudson KT, Medinsky MA. Differences in rates of benzene metabolism correlate with observed genotoxicity. Toxicol Appl Pharmacol 1996;136:4956.

3. Aksoy M. Hematotoxicity and carcinogenicity of benzene Environ Health Perspect 1989;82:193-7.

4. Hayes RB, Songnian Y, Dosemeci M, Linet M. Benzene and lymphohematopoietic malignancies in humans. Am J Ind Med 2001;40:117-26.

5. Maltoni CA, Ciliberti, G.Cotti, B Conti, Belpoggi F. Benzene an experimental multipotential carcinogen;results of the longterm bioassay performed at the Bologna Institute of Oncology. Environ Health Perspect 1989;82:109-24.

6. Gonasun LM, Witmer C, Kocsis JJ, Synder R. Benzene metabolism in mouse liver microsomes. Toxicol Appl Pharmacol 1973;24:398-406.

7. Sawahata T, Neal RA. Biotransformation of phenol to hydroquinone and catechol by rat liver microsomes. Mol Pharmacol 1983;23:453-60.

8. Arinç E, Adali O, Işcan M, Güray T. Stimulatory effects of benzene on rabbit liver and kidney microsomal cytochrome P-450 dependent drug metabolizing enzymes Arch Toxicol 1991;65:186-90.

9. Baccarelli A. [Occupational agents and endocrine function: an update of the experimental and human evidence, in Italian]. Med Lav 1999;90:650-70.

10. Xiao G, Pan C, Cai Y, Lin H, Fu Z. Effect of benzene, toluene, xylene on the semen quality and the function of accessory gonad of exposed workers. Ind Health 2001;39:206-10. doi: 10.2486/indhealth.39.206

11. Ward CO, Kuna RA, Snyder NK, Alsaker RD, Coate WB, Craig PH. Subchronic inhalation toxicity of benzene in rats and mice. Am J Ind Med 1985;7:457-73.

12. Matysiak VG. [The effects of benzene fumes on the functional activity of the hypophysis, adrenals and ovaries of white rats under experimental conditions, in Russian]. God Zb Med Fak Skopje 1968;14:98-100.

13. Snyder R, Witz G, Goldstein BD. The toxicology of benzene. Environ Health Perspect 1993;100:293-306.

14. Verma Y, Rana SVS. Sex differences in oxidative stress induced by benzene in rats. Indian J Exp Biol 2004;42:117 20.

15. Arendt J. Importance and relevance of melatonin to human biological rhythms. J Neuroendocrinol 2003;15:427-31.

16. Reiter RJ. Pineal rhythmicity, neural, behavioural and endocrine consequences. In: Shafii M, Shafii SL, editors. Biological rhythms, mood disorders, light therapy and pineal gland. Washington (DC): American Psychiatric Press Inc.; 1990. p. 41-66.

17. Klein DC, Moore RY. Pineal N-acetyl transferase and hydroxyl-indole-o-methyl-transferase: control by retino- hypothalamic tract and suprachiasmatic nucleus. Brain Res 1979;14:245-62.

18. Rana SVS, Rastogi S. Antioxidative enzymes in liver of rat treated with carbontetrachloride after parathyroidectomy. Physiol Chem Phys Med NMR 1993;25:41-7.

19. Rana SVS, Allen T. Influence of thyroxine and npropylthiouracil on nephrotoxicity of inorganic arsenic in rat. Toxicol Ind Health 2006;22:137-45.

20. Singh A, Rana SVS. Role of oxidative stress in testicular toxicity of benzene in rat. J Ecophysiol Occup Health 2009;9:11-6.

21. Singh S, Rana SVS. Amelioration of arsenic toxicity by Lascorbic acid in laboratory rat. J Environ Biol 2007;28(Suppl 2):377-84

22. Reiter RJ. Oxidative damage in the central nervous system: protection by melatonin. Prog Neurobiol 1998;56:359-84.

23. Sharma S, Rana SVS. Influence of melatonin on lipid peroxidation. Arh Hig Rada Toksikol 2010;61:11-8. doi: 10.2478/10004-1254-61-2010-1979

24. Reitman S, Frankel S. A colorimetric method for determination of serum glutamic-oxaloacitic and glutamic pyruvic transaminase. Am J Clin Pathol 1957;28:56-68.

25. Burtis CA, Ashwood ER. Tietz Fundamentals of Clinical Chemistry. Philadelphia (PA): WB Saunders; 1996. p. 370.

26. Kind RN, King EJ. Estimation of plasma phosphatase by determination of hydrolysed phenol with amino-antipyrene. J Clin Path 1954;7:322-6.

27. Pøndenphent J, Larson NE, Christiansen C. An easy and reliable method for determination of urinary hydroxyproline. Clin Chim Acta 1994;142:145-8.

28. Rana SVS, Verma Y. Biochemical toxicity of benzene. J Environ Biol 2005;26:157-68.

29. Park HJ, Oh JH, Yoon S, Rana SVS. Time dependent gene expression changes in the liver of mice treated with benzene. Biomarkers Insights 2008;3:191-201.

30. Rana SVS, Chaudhary N, Verma Y. Circadian variation in lipid peroxidation induced by benzene in rats. Indian J Exp Biol 2007;45:253-7.

31. Verma Y, Rana SVS. Gender differences in the metabolism of benzene, toluene and trichloroethylene in rat with special reference to certain biochemical parameters. J Environ Biol 2003;24:135-40.

32. Tan DX, Chen LD, Poeggeler B, Manchester LC, Reiter RJ. Melatonin: a potent endogenous hydroxyl radical scavenger. Endocr J 1993;1:57-60.

33. Hardeland R. Antioxidative protection by melatonin; multiplicity of mechanisms from radical detoxification to radical avoidance. Endocrine 2005;27:119-30.

34. Tan DX, Reiter RJ, Manchester LC, Yan MT, El-Sawi M, Sainz RM, Mayo JC, Kohen R, Allegra M, Hardeland R. Chemical and physical properties and potential mechanisms; melatonin as a broad spectrum antioxidant and free radical scavenger. Curr Top Med Chem 2002;2:181-98.

35. Allegra M, Reiter RJ, Tan DX, Gentile C, Tesorure L, Liurea MA. The chemistry of melatonin's interaction with reactive species. J Pineal Res 2003;34:1-10. doi: 10.1034/j.1600079X.2003.02112.x

36. Barlow-Walden LR, Reiter RJ, Abe M, Pablos M, MenendezPelaez A, Chen LD, Poeggeler B. Melatonin stimulates brain glutathione peroxidase activity. Neurochem Int 1995;26:497502 . 
37. Tomás-Zapico C, Coto-Montes A, Martínez-Fraga J, Rodríguez-Colunga MJ, Hardeland R, Tolivia D. Effects of delta-aminolevulinic acid and melatonin in the Harderian gland of female Syrian Hamsters. Free Radic Biol Med 2002;32:1197-204.

38. Aach RD, Szmuness W, Mosley JW, Hollinger FB, Kahn RA, Stevens CE, Edwards VM, Werch J. Serum alanine aminotransferase of donors in relation to the risk of nonA,non-B hepatitis in recipients: the transfusion-transmitted viruses study. N Engl J Med 1981;304:989-94.

39. Roberts WM. Variations in the phosphatase activity in the blood in disease. Br J Exp Pathol 1930;11:90-5.

40. Brensilver HL, Kaplan MM. Significance of elevated alkaline phosphatase in serum. Gastroenterology 1975;68:1556-62.

41. Campbell CB, Collins DM, Tongeren AV. Serum bile acids and other liver function tests in hepatocellular damage from carbontetrachloride ingestion. N Z Med. Journal 1980;91:38184.

42. Marshall WJ. Illustrated Textbook of Clinical Chemistry. Philadelphia (PA): Lippincott; 1988.
43. Johnson PJ. Role of the standard "liver function tests" in current clinical practice. Ann Clin Biochem 1989;26:46371.

44. Gregus Z, Watkins JB, Thompson TN, Klaassen CD. Depletion of hepatic uridine diphosphoglucuronic acid decreases the biliary excretion of drugs. J Pharm Exp Ther 1983;225:256-62.

45. Popper H, Underfriend S. Hepatic fibrosis, correlation of biochemical and morphological investigations. Am J Med 1970;49:701-21.

46. Reiter RJ, Tan DX, Mayo JC, Sainz RM, Leon J, Czarnocki Z. Melatonin as an antioxidant: biochemical mechanisms and pathophysiological implications in humans. Acta Biochim Pol 2003;50:1129-46.

47. Nabavi SF, Nabavi SM, Mirzaei M, Moghaddam AH. Protective effect of quercetin against sodium fluoride induced oxidative stress in rat's heart. Food Funct 2012;3:437-41. doi: 10.1039/c2fo10264a

48. Verma Y, Rana SVS. Endocrinal toxicity of industrial solvents - A mini Review. Indian J Exp Biol 2009;47:537-49. 


\section{Sažetak}

\section{MELATONIN MIJENJA JETRENU FUNKCIJU U ŠTAKORA IZLOŽENIH BENZENU}

Svrha je ovog ispitivanja bila utvrditi zaštitno djelovanje melatonina od oštećenja jetrene funkcije izazvanog benzenom u Wistar štakora. Nakon 30-dnevne primjene, melatonin je značajno snizio hepatosomatski indeks te razine bilirubina i hidroksiprolina u muških i ženskih štakora. Premda nije utjecao na aspartat aminotransferazu, povoljno je djelovao na alanin aminotransferazu i alkalnu fosfatazu. Naši rezultati upućuju na to da melatonin djelotvorno mijenja jetrenu funkciju u štakora izloženih benzenu, upravo zbog svojih antikoksidativnih svojstva.

KLJUČNE RIJEČI: alkalna fosfataza, antioksidansi, bilirubin, hidroksiprolin, serumske transaminaze

\section{CORRESPONDING AUTHOR:}

Professor Suresh V. S. Rana

Ch. Charan Singh University Department of Zoology

Meerut - 250004, India

E-mail:sureshvs_rana@yahoo.com 